\title{
PENGARUH TINGKAT RISIKO PEMBIAYAAN MUDHARABAH, MUSYARAKAH DAN MURABAHAH TERHADAP PROFITABILITAS PADA BANK SYARIAH MANDIRI DAN MUAMALAT PERIODE 2013-2017
}

\author{
Neneng Widayati \\ Fakultas Ekonomidan Bisnis \\ Universitas Islam Syekh - Yusuf Tangerang \\ nwidayati@unis.ac.id \\ DOI: https://doi.org/10.33592/jeb.v26i1.621
}

\begin{abstract}
ABSTRAK
Tujuan penelitian ini adalah untuk memperoleh bukti empiris tentang pengaruh tingkat risiko pembiayaan mudharabah, musyarakah dan murabahah terhadap profitabilitas pada Bank Syariah periode 2013 - 2017. Metode dalam penelitian ini adalah metode penelitian kuantitafif. Sampel yang digunakan yaitu laporan keuangan dari dua bank syariah periode 2013 - 2017. Data diolah menggunakan Microsoft Excel 2007 dan SPSS 25. Variabel terikat dari penelitian ini adalah Profitabilitas. Variabel bebas meliputi tingka risiko pembiayaan mudhrabah, tingkat risiko pembiayaan musyarakah dan tingkat risiko pembiayaan murabahah. Hasil penelitian ini menunjukan bahwa tingkat risiko pembiayaan mudharabah terhadap laba pada bank syariah tahun 2013 - 2017 terdapat pengaruh positif dan signifikan, hal ini dapat dilihat pada sig sebesar 0,000. Tingkat risiko pembiayaan musyarakah terhadap laba berpengaruh negatif dan tidak signifikan, hal ini dapat dilihat pada nilai nilai sig sebesar 0.284 . sedangkan tingkat risiko pembiayaan murabahah terhadap laba berpengaruh positif dan signifikan dengan nilai sig sebesar 0,001 .
\end{abstract}

Kata kunci : Tingkat risiko pembiayaan mudharabah, tingkat risiko pembiayaan musyrakah, tingkat risiko pembiayaan murabahah, dan profitabilitas.

\section{A. PENDAHULUAN}

Bank Syariah di Indonesia semakin berkembang dan terus meningkat secara konsisten dari waktu ke waktu. Survei pada Bank Indonesia November 2017, menunjukkan bahwa pembiayaan yang disalurkan perbankan syariah mencapai Rp277,6 triliun. Angka tersebut 
mengalami pertumbuhan hingga $15 \%$ atau lebih tinggi dibandingkan14,9\% pada pariode yang sama di tahun sebelumnya. Walaupun demikian, pembiayaan perbankan syariah hanya menyumbang 6\% dari seluruh penyaluran kredit bank umum, dan diproyeksikan di tahun 2018 bank syariah akan mencatatkan sejumlah kinerja yang baik.

Profitabilitas merupakan salah satu alat analisis bank yang digunakan untuk menilai kinerja manajemen dalam menghasilkan laba atau keuntungan dari operasi usaha suatu bank. Semakin baik kinerja keuangan bank maka profitabilitas yang diperoleh tinggi, sebaliknya jika kinerja keuangan bank kurang maksimal maka profitabilitas yang akan dicapai rendah. Jika profitabilitas yang rendah terus dibiarkan maka akan berdampak pada rendahnya citra bank dimata masyarakat. Penurunan kepercayaan masyarakat tersebut dapat mengakibatkan proses penghimpunan dana menjadi bermasalah.

Pembiayaan merupakan salah satu kegiatan bank syariah dalam menyalurkan dana yang diperoleh dari nasabah. Meningkatnya risiko pembiayaan disebabkan adanya peningkatan pembiayaan pada bank syariah. Pembiayaan menimbulkan ketidakpastian dalam memperoleh laba atau keuntungan dari dana yang telah disalurkan bank untuk membiayai proyek yang sudah disepakati antara bank dan nasabah. Adanya ketidakpastian tersebut mengakibatkan risiko yang tinggi pada bank yang berfungsi sebagai penyalur dana.

Selain menghasilkan keuntungan, pembiayaan yang telah disalurkan juga berpotensi menimbulkan risiko jika pengembalian atas jumlah pinjaman tidak sesuai dengan jangka waktu yang ditentukan seperti adanya pembiayaan bermasalah atau Non Performing Financing (NPF). Di mana jika presentase semakin tinggi maka semakin tinggi pula tingkat Non Performing Financing (NPF).

Pembiayaan mudharabah, musyarakah dan murabahah bermasalah yang terjadi pada bank syariah akan 
menimbulkan dampak yang tidak baik bagi pihak bank itu sendiri. Kredit bermasalah yang terjadi mengakibatkan hilangnya kesempatan memperoleh income (pendapatan) dari kredit yang diberikan, sehingga mengakibatkan berkurangnya perolehan laba dan menimbulkan pengaruh buruk bagi profitabilitas bank. Dengan demikian, masalah ini menjadi sangat penting untuk di lakukan penelitian agar bank syariah di Indonesia, dapat menarik minat masyarakat sebagai pemilik dana untuk menginvestasikan uang melalui penyertaan modal.

\section{B. Metodologi Penelitian}

\section{Desain Penelitian}

Metode dalam penelitian ini adalah metode kuantitatif. Penelitian ini dimaksudkan untuk mengetahui pengaruh tingkat risiko pembiayaan mudharabah, musyarakah dan murabahah terhadap profitabilitas Bank Syariah Mandiri dan Muamalat periode 2013-2017.

\section{Populasi dan Sampel Penelitian} Memurut Sugiyono (2017: 115), populasi adalah wilayah generalisasi yang terdiri atas obyek/subyek yang mempunyai kualitas dan karakteristik tertentu yang ditetapkan oleh peneliti untuk dipelajari dan kemudian ditarik kesimpulannya. Populasi dalam penelitian ini adalah laporan keuangan tahunan Bank Syariah Mandiri dan Muamalat periode tahun 2013-2017. Teknik dalam pengambilan sampel menggunakan sampling jenuh. Menurut Sugiyono (2017: 62), bahwa: "teknik sampling jenuh merupakan teknik penentuan sampel bila semua anggota populasi digunakan sebagai sampel.

\section{Metode Analisis Data}

\section{Regresi Linier Berganda}

Dalam penelitian ini menggunakan analisis regresi linier berganda untuk menguji antara variable independen terhadap variable dependen.

$$
\mathrm{Y}=\alpha+\beta 1 . \mathrm{X} 1+\beta 2 . \mathrm{X} 2+
$$

Dimana :

$\mathrm{Y}=$ Profitabilitas

$\mathrm{X}_{1}=$ Risiko Pembiayaan Murabahah 
$\mathrm{X}_{2}=$ Risiko Pembiayaan Musyarakah

$\mathrm{X}_{3}=$ Risiko Pembiayaan Mudharabah

$\beta_{1}, \beta_{2}, \beta_{3}=$ Koefisien regresi masing-

masing variable independen

$\mathrm{e}=$ error $: 0.05$

\section{Uji Signifikansi Parameter Individual}

\section{(Uji Statistik t)}

Menurut Ghozali (2016), Uji statistik t digunakan untuk menunjukan seberapa jauh pengaruh satu variabel independen secara individual dalam menerangkan variasi variabel dependen. Kriteria penerimaan dan penolakan hipotesis adalah:

- Apabila t hitung $<\mathrm{t}$ tabel, maka Ho diterima dan Ha ditolak (ada pengaruh signifikan)

- Apabila t hitung > t tabel, maka Ha diterima dan Ho ditolak di(tidak ada pengaruh signifikan)

Berdasarkan signifikansi dasar pengambilan keputusan adalah:

- Apabila signifikansi > 0,05, maka Ha diterima.

- Apabila signifikansi < 0,05, maka Ha ditolak.

\section{Uji Signifikansi Simultan (Uji Statistik}

F)

Menurut Ghozali (2016), uji signifikan tidak seperti uji t yang menguji signifikan koefisien persial regresi secara individu dengan uji hipotetsis terpisah bahwa setiap koefisien regresi sama dengan nol. Kriteria penerimaan dan penolakan hipotesis adalah:

- Apabila F hitung > F tabel pada tingkat kepercayaan 95\% dengan tingkat signifikansi 0.005 , maka $\mathrm{Ha}$ diterima dan Ho ditolak.

- Apabila F hitung < F tabel pada tingkat kepercayaan 95\% dengan tingkat signifikansi 0.005, maka Ha ditolak dan Ho diterima.

\section{Hasil Penelitian dan Pembahasan}

\section{Hasil Regresi Liner Berganda}

\section{Tabel 4.1}

Hasil Analisis Regresi Linier Berganda coefficients

\begin{tabular}{|l|l|r|r|r|r|c|}
\hline \multicolumn{2}{|c|}{ Model } & \multicolumn{2}{|c|}{$\begin{array}{c}\text { Unstandardized } \\
\text { Coeffecients }\end{array}$} & $\begin{array}{c}\text { Standardized } \\
\text { Coeffecients }\end{array}$ & T & Sig. \\
\hline & & \multicolumn{1}{|c|}{ B } & Std. Error & Beta & & \\
\hline 1 & (Constant) & 31296.922 & 67593468 & & 0.463 & 0.646 \\
\hline & (X1) Mudharabah & 0.507 & 0.103 & 0.653 & 4.925 & 0.000 \\
\hline & (X2) Musyarakah & -0.099 & 0.091 & 0.162 & - & 0.284 \\
& & & & 1.085 & \\
\hline & $(\times 3)$ Murabahah & 0.060 & 0.017 & 0.456 & 3.499 & 0.001 \\
\hline & a. Dependent Variabel: (Y) Profitabilitas \\
\hline
\end{tabular}

Sumber: Pengolahan data menggunakan SPSS 24 
Berdasarkan data pada tabel 4.1 dapat dibuat model regresi yang digunakan dalam penelitian ini yaitu :

$$
Y=31296,922+0.507 X 1-0,099
$$

Dari persamaan regresi regresi linier berganda, dapat dijelaskan beberapa hal antara lain :

a. Nilai konstanta 31296,922 yang berarti bahwa jika risiko pembiayaan mudharabah, risiko pembiayaan musyarakah dan pembiayaan murabahah terhadap laba, sebesar nilai konstanta yaitu 31296,922 .

b. Risiko pembiayaan mudharabah diperoleh nilai 0.507 yang berarti bahwa setiap 1 satuan terjadi perubahan (perbaikan) terhadap risiko pembiayaan mudharabah maka akan berdampak pada peningkatan Laba sebesar 0.507.

c. Risiko pembiayaan musyarakah diperoleh nilai - 0,099 yang berarti bahwa setiap terjadi perubahan (perbaikan) terhadap risiko pembiayaan musyarakah sebesar 1 satuan maka akan berdampak pada penurunan Laba sebesar -0,099.

d. Risiko pembiayaan murabahah diperoleh nilai 0,060 yang berarti bahwa setiap terjadi peningkatan terhadap risiko pembiayaan murabahah sebesar 1 satuan maka akan berdampak pada peningkatan Laba Bersih sebesar 0.060 .

\section{Hasil Uji Signifikansi Parameter Individual (Uji Statistik t)}

Tabel 4.2

Hasil Pengujian Individual coefficients

\begin{tabular}{|c|c|c|c|c|c|c|}
\hline \multirow{3}{*}{\multicolumn{2}{|c|}{ Model }} & \multicolumn{4}{|c|}{ Coefficients ${ }^{a}$} & \multirow{3}{*}{ Sign. } \\
\hline & & \multicolumn{2}{|c|}{$\begin{array}{c}\text { Understandardized } \\
\text { Coeffecient }\end{array}$} & \multirow{2}{*}{$\begin{array}{c}\begin{array}{c}\text { Standardized } \\
\text { Coeffecient }\end{array} \\
\text { Beta }\end{array}$} & \multirow[t]{2}{*}{$t$} & \\
\hline & & B & $\begin{array}{c}\text { Std.Erro } \\
\mathrm{r}\end{array}$ & & & \\
\hline 1 & (Constant) & 31296.922 & 67593468 & & 0.463 & 0.646 \\
\hline & $\begin{array}{l}\text { Risiko } \\
\text { Pembiayaan } \\
\text { Mudharabah }\end{array}$ & 0.507 & 0.103 & 0.653 & 4.925 & 0.000 \\
\hline & $\begin{array}{l}\text { Risiko } \\
\text { Pembiayaan } \\
\text { Musyarakah }\end{array}$ & -0.099 & 0.091 & 0.162 & -1.088 & 0.284 \\
\hline & $\begin{array}{l}\text { Risiko } \\
\text { Pembiayaan } \\
\text { Murabahah }\end{array}$ & 0.060 & 0.017 & 0.456 & 3.499 & 0.001 \\
\hline
\end{tabular}

Sumber: Pengolahan data menggunakan SPSS 25

Berdasarkan pada tabel 4.2 dapat diketahui pengaruh dari masing-masing variabel dapat dijelaskan sebagai berikut:

a. Variabel risiko pembiayaan mudharabah (X1) diperoleh nilai Sig sebesar $0,000(0,000<0,05)$, dan nilai $t_{\text {hitung }}$ sebesar 4.925 dibandingkan dengan nilai $t_{\text {tabel }}$ sebesar 2,03 ( $t_{\text {hitung }}>$ 
$\left.\mathrm{t}_{\text {tabel }}\right)$, makavariabel tersebut dinyatakan ada pengaruh positif dan signifikan. Sehingga keputusan Ho ditolak dan Ha diterima, artinya terdapat pengaruh yang positif dan signifikan antara risiko pembiayaan mudharabah terhadap laba.

b. Variabel risiko pembiayaan musyarakah (X2) diperoleh nilai Sig sebesar $0.284(0,284>0,05)$, dan nilai $\mathrm{t}_{\text {hitung }}$ sebesar -1.088 dibandingkan dengan nilai $t_{\text {tabel }}$ sebesar 2,03 ( $\left.t_{\text {hitung }}>t_{\text {tabel }}\right)$, maka variabel tersebut dinyatakan berpengaruh negatif dan tidak signifikan. Sehingga keputusan Ho ditolak dan $\mathrm{Ha}$ diterima, artinya bahwa variabel risiko pembiayaan musyarakah berpengaruh negatif dan tidak signifikan terhadap Laba.

c. Variabel risiko pembiayaan murabahah (X3) diperoleh nilai Sig sebesar 0,001 $(0,001<0,05)$, dan nilai $\mathrm{t}_{\text {hitung }}$ sebesar 3.499 dibandingkan $t_{\text {tabel }}$ sebesar 2,03 ( $t_{\text {hitung }}$ $\left.>\mathrm{t}_{\text {tabel }}\right)$, maka variabel tersebut dinyatakan signifikan. Sehingga Ho ditolak dan $\mathrm{Ha}$ diterima, artinya bahwa variabel risiko pembiayaan murabahah berpengaruh positif dan signifikan terhadap Laba.

\section{Hasil Uji Simultan (Uji F)}

Tabel 4.3

Hasil Uji F

\begin{tabular}{|c|c|c|c|c|c|c|}
\hline \multicolumn{7}{|c|}{ Anova $^{a}$} \\
\hline & Model & Sum Of Squares & df & Mean Squares & $\mathrm{F}$ & Sign. \\
\hline \multirow[t]{3}{*}{1} & Regression & 464260855809.467 & 3 & 154753618603.156 & 13.853 & $.000^{b}$ \\
\hline & Residual & 402158271915.908 & 36 & 11171063108.775 & & \\
\hline & Total & 866419127725.375 & 39 & & & \\
\hline \multicolumn{7}{|c|}{ a. Dependent Variabel: (Y) Profitabilitas } \\
\hline \multicolumn{7}{|c|}{ b. Predictors: (Constant), Risiko Pembiayaan Mudharabah (X1), Risiko Pembiayaan } \\
\hline
\end{tabular}

Sumber: Pengolahan data menggunakan SPSS 25

Berdasarkan dta pada tabel 4.3 menunjukkan bahwa nilai probabilitas (Sig) sebesar $0,00(0,000<0,05)$, dan nilai F hitung sebesar 13.853, kemudian dibandingkan antara $\mathrm{F}_{\text {hitung }}$ dengan $\mathrm{F}_{\text {tabel }}$, dengan menentukan nilai derajat bebas (df) untuk pembilang (dfl) dengan rumus $\mathrm{dfl}=\mathrm{k}-1$, didapat nilai $\mathrm{F}$ tabel sebesar sebesar 2,87, maka $F_{\text {hitung }}>F_{\text {tabel }}(13,853$ $>2,87$ ) Sehingga keputusannya adalah Ho ditolak dan $\mathrm{Ha}$ diterima, dapat disimpulkan bahwa secara simultan atau bersama-sama variabel independen 
Risiko Pembiayaan mudharabah, risiko pembiayaan musyarakah dan pembiayaan murabahah merupakan faktor yang mempengaruhi variabel dependen Laba.

\section{Simpulan}

Berdasarkan hasil penelitian maka dapat ditarik kesimpulan sebagai berikut:

1. Tingkat risiko pembiayaan mudharabah terhadap laba pada bank syariah tahun 2013 - 2017 terdapat pengaruh positif dan signifikan, hal ini ditunjukkan pada hasil uji t yang menyatakan nilai sig sebesar 0,000 dan nilai $t_{\text {hitung }}$ sebesar 4.925. Karena $t_{\text {hitung }}>t_{\text {tabel }}$ $(4,925>2,03)$ dan Sig sebesar $0,000(0,000<0,05)$

2. Tingkat risiko pembiayaan musyarakah terhadap laba pada bank syariah tahun 2013-2017 berpengaruh negatif dan tidak signifikan, hal ini ditunjukkan pada hasil uji $\mathrm{t}$ yang menyatakan nilai sig sebesar 0.284 , dan nilai thitung sebesar -1.088 . Karena $t_{\text {hitung }}>t_{\text {tabel }}(0,284>2,03)$ dan Sig sebesar $0.284(0.284>0,05)$.
3. Tingkat risiko pembiayaan murabahah terhadap laba pada bank syariah tahun 2013-2017 berpengaruh positif dan signifikan hal ini ditunjukkan pada hasil uji $\mathrm{t}$ yang menyatakan nilai sig sebesar 0,001, dan nilai $t_{\text {hitung }}$ sebesar 3.499. Karena $\mathrm{t}_{\text {hitung }}<\mathrm{t}_{\text {tabel }}(0,001<2,03)$ dan Sig sebesar $3.499(3.499>0,05)$.

4. Secara simultan Tingkat Risiko Pembiayaan mudharabah, risiko pembiayaan musyarakah dan pembiayaan murabahah berpegaruh terhadap laba dilihat dari hasil uji $\mathrm{F}$ $\operatorname{dimana} \mathrm{F}_{\text {hitung }}>\mathrm{F}_{\text {tabel }}(13,853>2,87)$ dan sig $<0,000(0,000<0,05)$.

\section{E. Daftar Pustaka}

Al Quran QS. Al-Baqarah ayat 198

Al Quran QS. Al-Baqarah ayat 275

Al Quran QS. Al-Baqarah ayat 282

Al Quran QS. An- Nisa ayat 12

Bank Indonesia, Peraturan No. 13/23/PBI/2011 tanggal 02 November 2011 : Risiko Pembiayaan.

Bank Indonesia, Surat Edaran No. 09/24/DPBS tanggal 30 Oktober 2007 : Sistem Penilaian Kesehatan Bank Berdasarkan Prinsip Syariah. 
Bank Indonesia, Surat Keputusan No. 32/34/KEP/DIR/12 Mei 1999 : Tentang Prinsip Kegiatan Bank Syariah.

Budisantoso, Totok dan Nuritomo (2013). Bank Dan Lembaga Keuangan Lainnya edisi 3,Yogyakarta : Salemba Empat.

Darsono, Ali Sakti, dan Ascarya (2015). Perbankan Syariah Di Indonesia, Jakarta: Raja Grafindo Persada

Fahrul et.al (2012), Pengaruh tingkat risiko pembiayaan musyarakah dan pembiayaan murabahah terhadap tingkat profitabilitas bank syari'ah (studi pada Bank Aceh Syari'ah Cabang Banda Aceh). Jurnal Akuntansi ISSN 2302-0164. Pascasarjana Universitas Syiah Kuala. Fakultas Ekonomi. Universitas Negeri Yogyakarta.

Fatwa Dewan Syariah Nasional, Pembiayaan Akad Mudharabah, No: 07/DSN- MUI/IV/2000.

Fatwa Dewan Syariah Nasional, Pembiayaan Akad Murabahah, No: 10/DSN- MUI/IV/2000

Fatwa Dewan Syariah Nasional, Pembiayaan Akad Musyarakah, No: 08/DSN- MUI/IV/2000.

Ghozali, Imam. (2016). Aplikasi analisis multivariate dengan program SPSS. Ikatan Bankir Indonesia (2009). Mengelola Bisnis Pembiayaan Bank
Syariah. Jakarta : PT Gramedia Pustaka Utama.

Kasmir. (2012). Manajemen perbankan.Jakarta: PT Rajagrafindo Persada.

Mulyaningsih, et.al (2016). Pengaruh NPF Pembiayaan Mudharabah dan NPF Pembiayaan Musyarakah Terhadap Profitabilitas Bank Umum Syariah.

Oktriani, Yesi. (2012). Pengaruh Pembiayaan Musyarakah, Murabahah, dan Mudharabah Terhadap Profitabilitas (Studi kasus pada PT. Bank Muamalat,Tbk).

Paramita, Cici. (2014). Analisis manajemen risiko pembiayaan pada Bank pembiayaan mudharabah terhadap tingkat profitabilitas bank syariah pembiayaan murabahah (Studi di PT. BPRS Tanmiya Artha Kediri).

Russely et.al. (2014), Analisis Pengaruh Pembiayaan Mudharabah dan Musyarakah Terhadap Tingkat Profitabilitas (Return On Equity) (Studi pada Bank Umum Syari'ah Yang Terdaftar di Bank Indonesia Periode 2009-2012). Jurnal Ekonomi.

Sugiyono. (2017). Statistika untuk penelitian. Bandung: CV.Alfabeta (2017). Metode penelitian bisnis. Bandung: CV. Alfabeta. 
UU No. 10 Tahun 1998 tentang Perubahan atas Undang-Undang No. 7. UU No. 21 Tahun 2018 tentang Perbankan Syariah.

UU No. 7 Tahun 1992 tentang Perbankan.

Yaya, Rizal dkk (2013). Akuntansi Perbankan Syriah, Teori dan Praktik Kontemporer, Yogyakarta : Salemba Empat www.ekonomy.okezone.com di akses pada tanggal 12 Maret 2018.

www.muamalat.co..id, www.syariahmandiri.co.id, 